\title{
Microfinance Sector and Sme Financial Suport in Albania
}

\author{
Alma Delija \\ Agricultural University of Tirana, Albania
}

\begin{abstract}
The creation of the microfinance sector and its functioning in Albania has played an essential role and has been and is a powerful tool for the development of small and medium enterprises (SMEs) of Albanian agribusiness. Microfinance has played an ever more decisive role in increasing output, reducing unemployment, improving the level of living conditions and welfare of the population, especially in rural areas, creating new jobs, contributing significantly to economic development Of the country. The growth and development of SMEs plays a fundamental role in the national economy, serving as a driving force in the country's economic development. Empirical evidence suggests that the growing SME sector and the dynamism of their development can strongly contribute to achieving a broad range of development objectives, such as: Achieving income distribution and poverty reduction; Creating employment; Savings mobilization; And production of goods and services that meet basic basic needs of the individual and society. Despite the great contribution to the growth and economic development of the country, the growth and development of SMEs in our country has been hampered by financial access, poor management skills, and lack of training opportunities and high input costs. Liquidities' sluggishness and low access to finance for SMEs is the biggest obstacle to them. SMEs have limited access to financial services provided by formal financial institutions to meet their liquidity and investment needs.
\end{abstract}

Keywords: SME, MFIs, Microfinance, Cooperation

\section{Introduction}

\section{Contingency test, and statistical analysis of the SME questionnaire}

\section{Analysis of questionnaire data}

The data used are based on the questionnaire built to assess the performance of MFIs and the impact of lending on SME development. The total sample of the survey consists of 310 observations after database cleansing. SME employees are asked about their demographic characteristics (age, gender, educational level, place of residence etc.), the main characteristics of business where they work as operating activity, organization form, funding sources, savings and institutions where i Deposit savings as well as lending alternatives. Further, the study is based on the impact of collateral on borrowing, interest rate on loans and products, services offered by MFIs in micro-enterprise development. Respondents were asked about the factors that influence the choice of the MFI as a lending option, the level of satisfaction on products, the services they offer. Information on knowledge of products, procedures for applying and receiving credit from MFIs was collected. Finally, the focus of this descriptive analysis is the impact that has brought the cooperation with the microfinance institutions, the most valued aspect in terms of cooperation, the contribution of loans received from MFIs, as well as the performance evaluation of microfinance institutions by SMEs.

\section{Contingency Analysis, Contingency Tables and Test X2}

This is one of the most commonly used analyzes, which consists in the use of techniques that examine the relationship between variables through contingency tables. This analysis is performed for categorical data for more than one variable 
and uses double-entry tables, also known as contingency tables. These tables summarize the information needed to perform statistical inferences and statistical testing of the correlation between variables based on observed data. Chisquare test is the method for testing the connection between row and column variables in a two-entry table. The zero hypothesis $\mathrm{HO}$ assumes that there is no link between the variables, so the variation of one variable is not associated with variation in the other variable. Alternative Hypothesis Formulated on the basis of the existence of a link between the two variables but does not specify the type of connection, which is done by examining the data. The Hi-square test is based on a statistic that measures the divergence of observed data from the expected values under the zero hypothesis that there is no link between the variables. In double-entry tables, the expected value for each cell is:

\section{Totals per row $\mathrm{x}$ total by column/Total number of observations}

Once the expected values are calculated, the hi-square statistic is calculated by collecting the squares of the differences between observed and expected values for each cell and dividing this amount with the expected value. So, the hi-square statistic is calculated with the following formula:

The distribution of this statistic is $X 2$ (Hi-square) with ( $r-1)(c-1)$ degree of freedom, where $r$ represents the number of rows of the two-entry table and $c$ represents the number of columns. This distribution only receives positive values and the $p$ value value for the $\mathrm{Hi}$-square test is the probability of observing a value at least as extreme as the test statistic for a $\mathrm{Hi}$ square distribution $(P(X 2 \geq X 2)$ with $(r-1)(C-1)$ degree of freedom.

$\mathrm{Hi}$-square tests are only valid when the size of the sample / selection is sufficient. There are some conditions that need to be met for the test to be valid. For example, for tables $2 \times 2$ to use the $x 2$ test, the selection dimension should be greater than 40 and if it is between 20 and 40 observations, the expected minimum value (frequency) should be at least 5 . For Other $x 2$ tables can be used if no more than $20 \%$ of table cells have expected frequencies of less than 5 and none of them is less than 1.

One of the limitations of data obtained in the database is that the variables are of nominal nature. This limits little to the ability to conduct regressive quantitative analysis, but does not prevent partial analysis of qualitative variables in the model. It is important to distinguish the relationships that these variables have with one another, in order to reach this dimension for the entire population.

\section{Results}

This section presents the results from the statistical analysis of the data. Initially a descriptive analysis is provided under subsection 4.1 followed by contingency analysis, section 4.2 . In the latter one will be tested hypothesis by Hi-Squared test and the correlation between variables will be shown under the hypotheses raised at the beginning of the paper.

\subsection{Descriptive Analysis}

This section presents descriptive data statistics from the questionnaire. The first part of the analysis shows demographic characteristics of choice, such as gender, age group, education, civil status, and place of residence in percentages and frequencies. Further, the analysis focuses on the characteristics of SMEs, their financing alternatives, and the impact of MFI borrowing on SME performance and development. The third and final part of the descriptive analysis focuses on the factors that determine the performance of micro-financial institutions by SMEs.

\subsubsection{General Sample Characteristics}

\section{Table 1: Demographic Characteristics of Selection}

\begin{tabular}{|l|l|l|}
\hline Characteristics & Frequency & Percentage \\
\hline Gender & & \\
\hline F & 192 & 61.9 \\
\hline
\end{tabular}




\begin{tabular}{|l|l|l|}
\cline { 3 - 3 } & 118 & 38.1 \\
\hline Age group & & \\
\hline $15-25$ & 17 & 5.5 \\
\hline $26-35$ & 82 & 26.5 \\
\hline $36-45$ & 82 & 26.5 \\
\hline $46-55$ & 74 & 23.9 \\
\hline $56-65$ & 46 & 14.8 \\
\hline $65+$ & 9 & 2.9 \\
\hline Educational level & & \\
\hline Primary & 14 & 4.5 \\
\hline 9 year old & 49 & 15.8 \\
\hline General secondary & 126 & 40.6 \\
\hline Secondary professional & 61 & 19.7 \\
\hline University & 60 & 19.4 \\
\hline Civil Status & & \\
\hline Married & 233 & 75.2 \\
\hline Single & 54 & 17.4 \\
\hline Coexistence & 11 & 3.5 \\
\hline Widow & 7 & 2.3 \\
\hline Divorced & 5 & 1.6 \\
\hline Residence & & \\
\hline The village & 238 & 76.8 \\
\hline City & 72 & 23.2 \\
\hline
\end{tabular}

Table 1 summarizes the main socio-demographic characteristics of the final sample, which consists of 310 applicants. The selection consists of 192 men and 118 women, corresponding respectively to about 61.9 and 38.1 percent of the sample. The age group 26-35 and 35-45 years of age dominates with 26.5 percent of the observations respectively for each and only 2.9 percent is represented by the age group over 65 . About 23.9 percent of respondents are $46-55,14.8$ percent are grouped in the 56-65 age group and only 5.5 percent belong to the $15-25$ age group. The majority of applicants or about 40.6 percent of them have general secondary education and about 19.4 percent have higher education. Only 4.5 percent have completed elementary education and 15.8 percent are 9 years old. With regard to civil status, it is noticed that most or about 75.2 percent of respondents are married. About 17.4 percent are single, 3.5 percent live in cohabitation, 2.3 percent are widowed, and only 1.6 percent belong to the divorced category. Most of the respondents or about 76.8 percent of them live in the village and around 23.2 percent in the city.

Table 2: SME Characteristics

\begin{tabular}{|l|l|l|}
\hline Characteristics & Frequency & Percentage \\
\hline Business activity & 77 & 24.8 \\
\hline Agriculture & 90 & 29 \\
\hline Livestock & 26 & 8.4 \\
\hline Builder & 74 & 23.9 \\
\hline Service & 43 & 13.9 \\
\hline Commerce & & 80.8 \\
\hline Form of business organization & 48.1 & 19.2 \\
\hline Individual Business & 11.4 & \\
\hline By partnership & & 70.6 \\
\hline Funding sources & 219 & 5.5 \\
\hline Income earned by the business & 17 & 19.7 \\
\hline Income from bank loans & 61 & 1.6 \\
\hline Fundraising sources from loans received from MFls & 5 & 0.6 \\
\hline Government grants for business assistance & 2 & 1.9 \\
\hline Funds from individuals of particular interest & 6 & \\
\hline Others & & \\
\hline
\end{tabular}


Table 2 presents the main descriptive features of SMEs. Data on key SME characteristics, how they operate, organization form, sources of funding, savings and savings deposits have been collected. Main activities are divided into agriculture, livestock, construction, service and trade. We see that the main share of livestock is about 29 percent, followed by agriculture by about 25 percent. Services occupy a weight of 24 percent and trade at 14 percent. Commercial construction businesses account for only 8.4 percent of the selection. Regarding the form of organization, the individual dominates with about 81 percent. Businesses with partnerships make up 19 percent of the sample. Regarding the sources of funding, we see that the majority or about 71 percent are the businesses that have the main source of funding, sales revenues. Businesses that have as their source of funding loans from MFIs account for about 20 per cent, compared to 5.5 per cent of businesses which have as source of financing loans received from second tier banks. We see that businesses that have other sources of funding are about 2.5 percent.

\section{Table 3: Characteristics of SMEs (continued)}

\begin{tabular}{|l|l|l|}
\hline Characteristics & Frequency & Percentage \\
\hline Saves income earned in business & & \\
\hline Yes & 238 & 78.3 \\
\hline No & 66 & 21.7 \\
\hline Savings deposit & & \\
\hline In the bank & 38 & 13.1 \\
\hline In microfinance institutions & 138 & 47.6 \\
\hline I keep it home & 114 & 39.3 \\
\hline
\end{tabular}

Individuals were asked if their businesses where they were employed saved the revenue they generated from sales and in which institution they deposited their savings. From the collected data we note that around 78.3 percent of SMEs save and that about 48 percent prefer to deposit savings in microfinance institutions compared to only 13 percent of businesses choosing second tier banks. About 39 percent prefer to keep their savings at home.

\section{Table 4: Lending alternatives}

\begin{tabular}{|l|l|l|}
\hline Characteristics & Frequency & Percentage \\
\hline Lending alternatives & & \\
\hline Banks & 52 & 16.8 \\
\hline IMF & 243 & 78.4 \\
\hline Other financial resources & 15 & 4.8 \\
\hline Apply and take credit in second-tier banks & & \\
\hline Never & 116 & 37.5 \\
\hline One time & 146 & 47.2 \\
\hline More than once & 47 & 15.2 \\
\hline Applied and received credit IMF & & \\
\hline Never & 46 & 14.8 \\
\hline One time & 107 & 34.5 \\
\hline More than once & 157 & 50.6 \\
\hline
\end{tabular}

Table 4 shows that the most preferred lending option is that of borrowing from the IMF by about 78 percent followed by lending by second tier banks by about 17 percent. We see that we have a higher percentage of SMEs that have not applied and received loans from second tier banks, about 38 percent, compared with MFI borrowing by about 15 percent. Meanwhile, businesses that have applied for bank loans at least once are about 47 percent compared to about 34.5 percent 
of SMEs that have chosen microfinance institutions. We also see that the percentage of businesses that have applied more than once in the IMF is higher than in the second tier banks. This result is due to the ease of application and the greater favorability of SMEs by MFIs.

\section{Factors affecting the selection of an MFI as a lending option}

\section{Chart 1: SME crediting preferences}

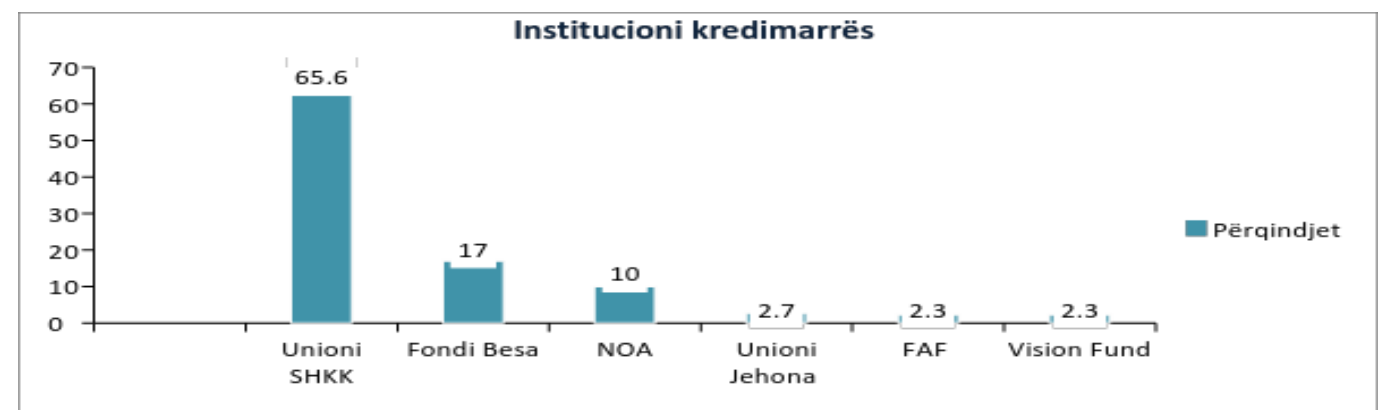

Graph 1 shows that about 66 percent of SMEs have benefited from the microfinance institution 'Union ASC in the last five years. About 17 percent have benefited from 'Besa Fund', about 10 percent from 'NOA', followed by 'Union Jehona' with 2.7 percent and 2.3 percent respectively from 'FAF' and 'Vision Fund Albania'.

Chart 2. Factors affecting the selection of the MFI as a borrowing alternative

The graph shows that one of the factors influencing the choice of MFIs as a borrowing alternative is the well-known procedures with around 23 percent. Another factor of choice is the rapid preparation of documentation and ease of use, at about 22 percent, respectively. We note that the interest rate is estimated to be lower than the other factors in the election with only about 13 percent. Fast loan disbursement is estimated by 12 percent of SMEs and only 10 percent of them choose the IMF because no collateral is required for obtaining the loan.

From the data presented in the chart above, we see that the percentage of relatively satisfied SMEs is prevalent and only a small part has reservations about the level of satisfaction they receive from the products / services offered by microfinance institutions. Concretely, around 47 percent of respondents are relatively satisfied. About 35 percent of them are satisfied with the products and around 17 percent are indifferent to the assessment.

Respondents were asked to evaluate the cooperation with the micro-medical institutions so far. Specifically, the grade five regards the 'I did not cooperate' rating, the grade six 'satisfied enough' grade, the seventh grade belongs to the 'relatively satisfied' grade, the eight grade rating "satisfied by the co-operation", the grade nine rating "very satisfied by Cooperation "and grade ten expresses the utmost appreciation," I am a regular member, even I have referred to relatives to cooperate with the IMF institution ". From Graph 4.8 we can see that about 17 percent of SMEs have not cooperated with MFIs, and about 22 percent of those who cooperated were satisfied with cooperation. About 19 percent are relatively satisfied, about 13 percent are satisfied and about 16 percent express a high level of satisfaction. There are only 13.5 percent SMEs that consider the business as regular members and more referrals to other businesses for the products / services that MFIs offer.

Asked what aspect SMEs consider most in terms of cooperation with the IMF, it is noticed that the most important is the possibility of obtaining low interest rate loans. This finding expresses about 35 percent of SMEs. It is worth mentioning that significant importance is also taken by firms that estimate the possibility of increasing the loan amount by about 26 percent. A percentage of 23 estimates the short time of loan disbursement. And recently 17.1 percent of them estimate the reduction 
of bureaucratic procedures. In the analysis above, we saw the impact of cooperation with microfinance institutions on increasing income, welfare, creating new products / services, opening up new micro-enterprises, etc. Graph 4.12 shows the impact of microfinance institutions in the community. It is concluded that the most positive impact of the respondents in the community is marked by the poverty reduction of about 40 percent of firms compared to job creation by 28 percent. About 16 percent estimate the improvement of environmental conditions. Through MFI activities, women's participation in business has increased, which is estimated by 9.6 percent of respondents. MFIs enable the preservation, development of the tradition, culture and values of the community and such a factor is estimated by about 7 percent of respondents.

\section{Contingency tables}

From the cross-sectoral disclosure of the main business activity and the number of applications for loans from second-tier banks (Table A1) it is noticed that the relationship between them is statistically insignificant at level 5 and 10 percent. While referring to the Hi-square test for the link between the main business activity and the number of applications for loans from MFIs (Table A2), we see that it is statistically important at the 5 percent level and the Cramer's V correlation coefficient is around 20 percent. Of the businesses that have applied for loans more than once, about 35 percent operate in livestock, about 30 percent operate in agriculture, and only 5 percent have major construction activity. Such a figure is about 9 percent for the firm's business activity. At the same time, if from agricultural and livestock businesses around 61 per cent applied for MFI loans more than once, only 32 per cent with the same application frequency are businesses with commercial activity, and only 30.8 per cent are those with activity Construction.

Table A3 represents the cross-disclosure between the main business activity and the borrowing alternatives. Note that the $\mathrm{Hi}$-Squared test for this link is invalid. Thus, it is not supposed that no more than $20 \%$ of the table cells have expected frequencies of less than 5 and none of them is less than 1.

From the Hi-square test results for the link between the main business activity and the difficulty of borrowing from MFIs, we see that the link is statistically significant at the 10 percent level. The link Lambda coefficient is zero, and it is recommended that Cramer's $V$ is used for combinations of nominal variables, which for this connection is 0.16 . From Table A4 of the contingency we see that even though it resulted that businesses with construction and trade activity to apply less for loans from MFIs, they have less difficult process than agricultural and livestock businesses. Specifically, if less than 7 percent of construction businesses and about 10 percent of those trading have no difficulty in borrowing from MFIs, 25 percent and 29 percent of agricultural and livestock businesses respectively face difficulties in applying. Such a result is about 24 percent for businesses operating in services.

From the crossroads of the form of business organization and the application and receipt of credit by second-tier banks (Table A5), it is noted that the relationship between them is statistically significant at the 5 percent level. The Cramer's $V$ connection coefficient is around 19 percent. About 41 percent of individual businesses have never applied for loans from second tier banks, compared to about 25 percent of joint ventures. However, from businesses that have applied more than once, about 64 percent are individual businesses and only 35.6 percent are affiliated businesses. So, we can not say the more organized the business structure, the higher the applications for loans in second tier banks. Such a result may be the attribute of higher frequencies of individual businesses compared to those in partnership.

Table A6 shows the results of the Hi-square test for the link between the form of business organization and application / borrowing from MFIs. It is noted that the linker is statistically significant at the 5 percent level and the Lambda link coefficient is only 0.038 . Despite the weak linkage, from businesses that have applied more than once for loans from MFls, about 81 percent are individual businesses and only 12 percent are partnership businesses. If only 9 percent of individual businesses have never applied for loans from MFIs, such figure is about 41 percent for partnership businesses. This can be argued by the fact that the latter have greater initial capital than single-owner businesses. However, as long as business life expectancy in the market and initial capital (which are not the focus of the study) is not required, the argument can be taken as an assumption. 
Hi-square test of business form and borrowing alternative (Table A7) is invalid because it does not meet the assumption that no more than 20 percent of cells have expected frequencies of less than 5 and that none of the Should be less than 1. From the cross-section of the form of business organization and the lack of borrowing from the MFls, we note their relationship is statistically significant at the 5 percent level. The Phi connection coefficient is (21.7) percent. The negative link is shown by the fact that business partnerships make it harder for the borrowing process than for individual businesses. Specifically, from firms that do not face difficulties in applying for borrowing, about 87 percent are individual businesses compared to only 13 percent of partnerships. However, such a result is a specific case of firms surveyed and it is assumed that other factors, such as bureaucracy of lending institutions, or the amount of credit, periods, and financial performance of SMEs.

From the cross-disclosure of loan interest rate impact on microprocessing development and the application of loans by MFIs (Table A9), we note that the correlation between them is statistically significant at 5 per cent. Kendall's correlation coefficient $\mathrm{T}$ of this correlation is (17) percent. Thus, the more negative the impact of interest rates on loans, the lower will be the number of applications for borrowing from MFIs. Concretely, by SMEs that note the positive impact of interest rates on loans in their development, 4 percent have not applied any time, while about 54 percent have applied more than once. Of the firms that claim negative impact, around 63 percent have never applied for loans, and only 16 percent have applied more than once. The link is also distinguished by the column-based interpretation, where firms with more than one MFI Ioan application only 2 per cent think that interest rates have a negative impact on micro-enterprise development, while 69 per cent are firms that find the impact Positive and about 29 percent of them think that interest rates on MFI loans have no impact.

Table A10 shows the results of the Hi-square test for the link between the application for loans from MFIs and the reasons for applying for loans in these institutions, the correlation between them is statistically insignificant at the level of 5 per cent despite the validity of the test. From the cross-study of MFI loan applications and the impact of SME cooperation with them in the development of their micro-enterprises, it is noted that the link is statistically significant at 5 per cent level and Cramer's V coefficient is about 23 per cent. From Table A11 we see that from businesses that think that cooperation with MFIs has brought about growth in production, about 6 percent have never applied for loans, compared to 49 percent of businesses that have applied more than once and about 45 percent Have applied only once. Of the businesses that find increase in investment, only about 13 percent have not applied or received loans from MFls, and 53 percent are interested or have obtained more than one loan. The same trend can be seen in the effect on growth of the border, where by the SMEs claiming staff growth as a result of borrowing, about 56 percent have applied or received more credits than once compared to about 12 percent who have never applied. The highest variation is identified in revenue growth where about 72 percent of firms claiming an increase in business income have applied once. Such a figure is only 5 percent for businesses that have never cooperated with MFIs. Regarding the effect on improving technology, it can be said that not necessarily firms use borrowing to invest in technology, or not all aim to improve it. This happens in the case of businesses with mainstream construction and livestock activities where labor is dominant input to technology.

Table A11 shows the Hi-square test results for the link between applying and receiving MFI credit and the aspects of borrowing that SMEs most appreciate. We find that the correlation between them is statistically significant at the 5 percent level and the Cramer's V correlation coefficient is around 21 percent. Of businesses that estimate credit volume growth, about 57 percent have applied or received loans more than once and only 19 percent have never cooperated. The high percentage of the latter can be the attribute of the assessment of the support that MFIs provide to SMEs. Of the businesses that estimate the reduction of burroctric procedures, less than 8 percent have never cooperated with MFIs, compared to about 47 per cent who have applied once, and about 45 per cent who have received loans at least once. 


\section{Findings, Conclusions and Recommendations}

The relation between the main business activity and the number of applications for loans from second tier banks is statistically insignificant at 5 and 10 percent. While referring to the Hi-square test for the link between the main business activity and the number of applications for loans from MFIs, it was found that it is statistically significant at the 5 percent level and the correlation coefficient is around 20 percent. We saw no link between main business activity and borrowing alternatives, while the link between the main business activity and the difficulty of borrowing from MFls is statistically significant at the 10 percent level. The correlation coefficient for this link is 0.16 . Although it resulted that businesses with construction and trade activity to apply less for MFI loans, they have less difficulty in the process than agricultural and livestock businesses.

The link between the form of business organization and the application and receipt of credit by second tier banks is statistically significant at the 5 percent level. The correlation coefficient of connection is about 19 percent. It was noted that for this connection we can not say that the more organized the business structure, the higher are the applications for loans in second tier banks. Such a result may be the attribute of higher frequencies of individual businesses compared to those in partnership. The link between the form of business organization and the application / borrowing from MFIs is statistically significant at the 5 percent level and the bond coefficient is only 0.038 .

Despite the weak link, from businesses that have applied more than once for loans from MFIs, there are more individual businesses than those with partnerships. This can be argued by the fact that the latter have greater initial capital than single-owner businesses. However, as long as business life expectancy in the market and initial capital (which are not the focus of the study) is not required, the argument can be taken as an assumption. The link between the form of business organization and the lack of borrowing from MFIs is statistically significant at the 5 percent level. The Phi connection coefficient is (21.7) percent. The negative link is shown by the fact that business partnerships make it harder for the borrowing process than for individual businesses. However, such a result is a specific case of firms surveyed and it is assumed that other factors, such as bureaucracy of lending institutions, or the amount of credit, periods, and financial performance of SMEs.

The link between the impact of loan interest rates on microfinance development and the application of loans by MFls is statistically significant at 5 per cent. Kendall's correlation coefficient $T$ of this correlation is (17) percent. Thus, the more negative the impact of interest rates on loans, the lower will be the number of applications for borrowing from MFIs. Rather, the link between applying for loans from MFIs and the reasons for applying for loans to these institutions shows that the relationship between them is statistically insignificant at the 5 percent level despite the validity of the test. On the other hand, the link between applying for loans from MFIs and the impact of SME co-operation with them in the development of their micro-enterprises is statistically significant at 5 per cent level and Cramer's V coefficient is around 23 per cent.

The Hi-square test results for the link between applying and obtaining credit from the MFIs and the aspects of the borrowing that SMEs estimate most show that their relationship is statistically significant at the 5 percent level and the Cramer's V correlation coefficient is About 21 percent.

The Hi-square test of the link between the level of recognition of products / services that MFIs offer and their application or borrowing shows that the link is statistically significant at the 5 percent level. Kendall's coefficient $\mathrm{T}$ for this link is about 31 percent. So the higher the level of recognition, the higher the frequency of applying or receiving the loan. The relationship between the level of recognition of the products / services offered by MFIs and the aspects that SMEs value most from their acquisition results statistically significant at the 5 percent level and Cramer's V coefficient is around 19 percent.

Also, the link between evaluating cooperation with MFIs and applying or obtaining loans from them is statistically significant at the 5 percent level. The Kendall's coefficient of $\mathrm{T}$ is about 40 percent. It is evident that firms that have not obtained loans at any single time can not estimate the level of satisfaction from co-operation with MFIs. The relationship between the 
assessment of cooperation with the performance aspects that SMEs best value at MFIs is statistically significant at 5 per cent level and the Cramer's $V$ coefficient is about 26 per cent.

The same conclusion is said about the link between the assessment of cooperation with the MFIs and the reasons for their cooperation. The Cramer's V correlation coefficient is around 19 percent. Of the firms that share a high level of satisfaction, about 10 percent more or 22 percent estimate well-defined procedures, 24 percent of firms conclude that documentation is prepared quickly and only 6 percent estimate the rapid credit delivery.

Even the link between applying or receiving credit from MFIs and assessing collateral demand is statistically significant at the 5 percent level. Kendall's coefficient of $\mathrm{T}$ is about 14 percent. Also, the correlation between collateral demand rating and borrowing difficulty is statistically significant at the 5 percent level and the Cramer's $V$ correlation coefficient is around 41 percent. Specifically, from businesses that have difficulties in borrowing from MFIs, most consider the demand for high collateral and the rest consider it low. The relationship between the difficulty of borrowing from MFIs and the impact of interest rates on micro enterprise development is statistically significant at 5 per cent level and the Cramer's $V$ correlation coefficient is around 30 per cent.

\section{References}

[1] Arsyad L. (2005) An assessment of performance and sustainability of Microfinance

[2] Institutions: A case study of Village credit institutions in Gianyar, Bali, Indonesia,

[3] unpublished $\mathrm{PhD}$ thesis, Flinders University, Australia

[4] Arsyad, L. (2005). An Assessment of Microfinance Institutions Performance: The Importance of Institutional Environment. International Journal of Business, 7(3), 391-427.

[5] Aghion, B., \& Morduch. (2005). The Economics of Microfinance. Cambridge, Mass: London: MIT Press.

[6] Annim, S. K. (2010). Microfinance Efficiency Trade-Offs and Complementarities: University of Manchester Brooks, World Poverty Institute

[7] Akhter, S. and Daly, K.J. (2009), Finance and Poverty: Evidence from Fixed Effect Vector Decomposition. Emerging Markets Review, 10, 191-206.

[8] ASA. (2008, May 17). key features of ASA's innovative management. Retrieved Jul 03, 2009, from Asoociation of Social Advancement: www.asa.org.bd/about_salient_feature.html

[9] Auren \& Krassowska, (2004) Financial services, Institutions for Small Scale Enterprise in Uganda. Fountain publishers Kampala Uganda.

[10] Biryabarema, E. (1998), Small Scale Business and Commercial Banks in Uganda. Kampala, Makerere University Press.

[11] Coleman, B. (2006). Microfinance in Northeast Thailand: Who Benefits and How Much? World Development 34(9) , 16121638.

[12] Chijoriga, M.M. and Cassimon(1999) "Micro Enterprise Financing: Is there a Best model?" in

[13] Rutashobya and Olomi(eds). African Entrepreneurship and Small Business Management, DUP Dar es Salaam.

[14] Hossain, M. (1988), "Credit for the Alleviation of Rural Poverty: The Grameen Bank in Bangladesh". Washington, D.C.: IFPRI, Research Report No. 65.

[15] Hermes, N., Lensink, R., \& Meesters, A. (2011), Outreach and efficiency of microfinance institutions. World Development, 39(6), 938-948.

[16] Hulme, D. and Mosley P. (1996a), "Finance Against Poverty", Volume 1. London and New York: Routledge

[17] MFI annual reports in Albania

[18] Zeller, M., \& Meyer, R. (2002). Improving the performance of microfinance: Financial sustainability, outreach and impact, in: Zeller, M. \& Meyer, R. L.: The triangle of microfinance. Baltimore: The Johns Hopkins University Press. 